University of Nebraska - Lincoln

DigitalCommons@University of Nebraska - Lincoln

Publications from USDA-ARS / UNL Faculty

U.S. Department of Agriculture: Agricultural

Research Service, Lincoln, Nebraska

November 1987

\title{
Conservation Tillage and Irrigation Effects on Corn Root Development
}

\author{
R. L. Newell \\ USDA-ARS \\ Wallace Wilhelm \\ University of Nebraska-Lincoln, wwilhelm1@unl.edu
}

Follow this and additional works at: https://digitalcommons.unl.edu/usdaarsfacpub

Part of the Agricultural Science Commons

Newell, R. L. and Wilhelm, Wallace, "Conservation Tillage and Irrigation Effects on Corn Root Development" (1987). Publications from USDA-ARS / UNL Faculty. 113.

https://digitalcommons.unl.edu/usdaarsfacpub/113

This Article is brought to you for free and open access by the U.S. Department of Agriculture: Agricultural Research Service, Lincoln, Nebraska at DigitalCommons@University of Nebraska - Lincoln. It has been accepted for inclusion in Publications from USDA-ARS / UNL Faculty by an authorized administrator of DigitalCommons@University of Nebraska - Lincoln. 


\title{
Conservation Tillage and Irrigation Effects on Corn Root Development ${ }^{1}$
}

\author{
R. L. Newell and W. W. Wilhelm²
}

\begin{abstract}
The effects of conservation-tillage practices on the root environment of corn (Zea mays L.) may differ with varying amounts of irrigation. Dryland, 50\% irrigation, and $100 \%$ irrigation treatments were applied in combination with disc, no-tillage, and a postemergence chisel treatment designed to allow rapid infiltration of irrigation water. The study was conducted during the 1980 growing season at the Nebraska Agricultural Experiment Station near Mead, NE, on a Sharpsburg silty clay loam (fine, montmorillonitic, mesic Typic Argiudolls). Root samples were taken to $1.50 \mathrm{~m}$ in $0.15-\mathrm{m}$ increments. Sampling was done at 60 (V8), 77 (V14), and 90 (R2) days after planting. Root length per soil volume as a function of depth from the soil surface was characterized using hybrid B73 $\times$ Mo17. Root length exhibited linear and often quadratic distribution over sampling depths at all sampling dates. The $100 \%$ irrigation treatment exhibited greatest total profile (0- to $1.5-\mathrm{m})$ and surface (0- to 0.15-m) root length at $\mathbf{R 2}$. Dryland and $50 \%$ irrigation treatments were associated with relatively greater root length proliferation deep in the soil profile. Differences in root length distribution were not as pronounced at stages V8 and V14. Chisel and no-tillage treatments, with crop residues at the soil surface, resulted in greater surface (0- to 0.15-m) and total profile root length than discing. Corn roots tended to explore the lower profile to a greater extent under water stress conditions. This phenomenon, in conjunction with soil water conservation by no-tillage methods, may allow irrigators to increase water-use efficiency by better use of stored soil moisture.
\end{abstract}

Additional index words: No tillage, Reduced tillage, Water regime, Water stress, Root distribution, Zea mays $\mathrm{L}$.

$\mathrm{I}^{\mathrm{R}}$ RIGATED corn (Zea mays L.) comprises a significant portion of total U.S. corn production. It is estimated that future additions in irrigated acreage will be with center-pivot systems (Gilley and Mielke, 1980). Recent concerns about irrigation energy requirements have led to widespread use of low-pressure center-pivot systems. These low-pressure systems may induce runoff and soil erosion due to their high water application rates unless conservation practices are employed. Surface residues have also been shown to reduce evaporative water loss from the soil surface (Hill and Blevins, 1973) and were associated with reduced runoff (Van Doren and Triplett, 1969).

Soil water and temperature regimes and other soil physical factors can affect corn root growth. These soilrelated factors often differ among various tillage systems. Crop residues often associated with conservation-tillage practices have been shown to reduce soil surface temperature (Griffith et al., 1973), which can affect the direction of root growth (Chaudhary and Prihar, 1974). Chaudhary and Prihar (1974) also found that conventional tillage encouraged earlier and deeper penetration of corn roots into the soil profile than did no-tillage, but no-tillage corn had more roots in the top $0.20 \mathrm{~m}$ of soil during early growth stages. It is clear that tillage systems alter the soil environment, thus providing a potential for affecting corn root distribution within the soil.

Irrigation has been shown to affect total corn root weight and distribution. Irrigated corn produced more total root mass than dryland corn in one Kansas study (Mayaki et al., 1976), but dryland corn had a greater proportion of its total root mass below $0.30 \mathrm{~m}$ in the soil. Robertson et al. (1980) found both irrigation fre- quency and total water application affected root distribution and total root length. Moderate water stress imposed by light, infrequent irrigations was associated with the greatest total root length for corn. The objective of the present study was to characterize corn root length distribution within the soil profile as affected by irrigation and tillage.

\section{MATERIALS AND METHODS}

\section{Cultural Practices}

Tillage and irrigation treatments were established in 1977 at the Nebraska Agricultural Experiment Station near Mead, $\mathrm{NE}$, as part of a large study to determine the feasibility of low-pressure center-pivot irrigation systems (Gilley et al., 1983; Wilhelm et al., 1985). Corn was grown continuously from 1977 through 1980 on a Sharpburg silty clay loam soil (fine, montmorillonitic, mesic Typic Argiudolls) of 0 to $2 \%$ slope. Corn (hybrid B73 $\times$ Mol7) was planted with a notillage planter on $25 \mathrm{Apr}$. 1980 in $0.91-\mathrm{m}$-wide rows. Fertilizer applications totaled $175 \mathrm{~kg} \mathrm{~N}$ and $11 \mathrm{~kg} \mathrm{P}^{-1}$, with the majority of $\mathrm{N}$ applied as anhydrous ammonia (injected into the soil at $0.15 \mathrm{~m}$ ) at growth stage V4. Atrazine [2chloro-4-(ethylamino)-6-(isopropylamino)-s-triazine] and alachlor [2-chloro-2',6'-diethyl-N-(methoxymethyl)acetanilide] were applied preemergence at 3.2 and $2.3 \mathrm{~kg} \mathrm{ha}^{-1}$, respectively, in $185 \mathrm{~L}$ water. An additional posemergence application of atrazine at $2.3 \mathrm{~kg} \mathrm{ha}^{-1}$ plus $1.2 \mathrm{~L}$ petroleumbased crop oil in $185 \mathrm{~L}$ water was made on 9 June 1980. Cultivation with $0.33-\mathrm{m}$ sweeps controlled weeds at growth stage V5.

Tillage treatments included (i) discing to a $0.10-\mathrm{m}$ depth prior to planting, (ii) no-tillage, and (iii) a postemergence chisel treatment. The chisel treatment was performed at growth stage V6. Straight chisel shanks were positioned midway between rows and were set to run at a $0.35-\mathrm{m}$ depth. This somewhat unconventional chisel treatment allowed maintenance of corn residue at the soil surface while leaving an open slot $25 \mathrm{~mm}$ wide that allowed rapid water infiltration.

Irrigation treatments were based on IRRIGATE, an irrigation scheduling model developed by Tscheshke et al. (1978) using soil water balance to determine irrigation dates. Soil water balance was monitored at several field locations with gypsum blocks and a neutron probe. Irrigation treatments, applied through a center-pivot irrigation system, supplied 100,50 , and $0 \%$ (dryland) of crop water requirements. The unusually dry 1980 growing season provided only $354 \mathrm{~mm}$ of rainfall (129 mm below normal) from May through September. Drought conditions were accentuated by high air temperatures which averaged greater than $1^{\circ} \mathrm{C}$ above normal, with 47 days exceeding $35^{\circ} \mathrm{C}$. Consequently, five irrigations were needed for a total of 171 and $90 \mathrm{~mm}$ water in 100 and $50 \%$ irrigation treatments, respectively. Dryland treatments received no supplemental irrigation. Irrigation

\footnotetext{
'Contribution from the USDA-ARS, in cooperation with the Nebraska Agric. Res. Div. Published as Paper no. 7931, Journal Series Nebraska Agric. Res. Div. Received 14 Oct. 1985.

Field sales agronomy manager, Pioneer Hi-Bred International, Inc., Tipton IN 46072 (former graduate assistant, Univ. of Nebraska-Lincoln, Lincoln, NE); and plant physiologist (USDA-ARS) and associate professor (Agronomy Dep., Univ. of Nebraska-Lincoln, Lincoln NE 68583), respectively.
}

Published in Agron. J. 79:160-165 (1987). 
dates and irrigation amounts as well as total precipitation during this study have been reported by Wilhelm et al. (1985).

\section{Root Sampling and Processing}

Soil cores for measuring roots were collected from plots at 60,77 , and 90 days after planting, which coincided with the 8-leaf (V8), 14-leaf (V14), and blister (R2) stages, respectively. A Giddings ${ }^{3}$ (Giddings Machine Co., Ft. Collins, $\mathrm{CO}$ ) soil coring machine mounted on a high-clearance spray tractor (Bausch et al., 1977; Mielke and Wilhelm, 1983) was used to drive a 76-mm-diam coring tube to a depth of 1.50 $\mathrm{m}$. Cores were centered $0.10 \mathrm{~m}$ from the base of randomly chosen corn plants at $90^{\circ}$ to the row direction. Soil cores were separated into $0.15-\mathrm{m}$ sections, placed in polyethylene bags, and stored at $-20^{\circ} \mathrm{C}$ until processed.

Processing of soil cores involved manual separation of root tissue from soil and debris after thawed core sections were gently washed in water. The washing procedure was similar to that described by Ward et al. (1978). Root tissue (which appeared fresh and light in color) was stored in a 1:1 mixture of ethanol and deionized water until root length could be determined. Root length was determined by the Newman (1966) technique with apparatus described by Wilhelm et al. (1983) and projected photographic images of roots. An aqueous solution of the vital stain crystal violet $(100 \mathrm{~g}$ $\mathrm{m}^{-3}$ ) was used to stain root tissue in order to increase contrast and resolution of fine roots on the photographic negatives. Images were projected onto a photodiode that traversed a grid pattern. The number of intersections of the photodiode with stained root images was related to manually determined sample root length by a quadratic equation with $r^{2}=0.98$

\section{Experimental Design and Analysis}

Treatments were arranged as split plots within a randomized, complete block design with three replications. Irrigation levels were applied to whole plots, and tillage treatments were applied to subplots. Separate ANOVA tables were generated for each of the three sampling dates.

A priori orthogonal comparisons (independent, single df comparisons) between tillage and irrigation treatments were used to compare possible treatment differences based on the distribution of corn roots within the soil profile. Selection of this method of comparison provided increased power to compare broad trends in root distribution because relative lengths of roots within each soil profile depth increment were considered together in the orthogonal comparison. Linear and quadratic distributional effects (over the depth of sampling) were tested using the method of orthogonal polynomials in regression (Steel and Torrie, 1980). This method allowed comparison of treatments by considering total profile root distribution, giving equal weight to each sampling depth increment. Coefficients for linear and quadratic components of the data were used to compare profile root distribution of treatments via single df comparisons using regression analysis. The method of orthogonal polynomial comparisons was chosen over multiple comparison procedures (such as the LSD test) because of its greater power for discerning broad trends in the root distribution data. Nelson and Rawlings (1983) gave a description of the appropriate use of orthogonal comparisons vs. multiple comparison procedures.

\section{RESULTS}

Root length for all treatments generally decreased as soil depth increased. Thus, orthogonal polynomials showed that root length exhibited a highly significant linear distribution pattern within the soil profile. Sim- plified quadratic distribution was also observed at V8 before roots proliferated deep within the soil profile.

\section{Irrigation Effects}

There were no significant effects of irrigation levels on root length distribution at V8. There was a trend, however, toward greater root length with dryland treatments at the $0.30-$ to $0.90-\mathrm{m}$ soil depth. This trend continued into V14 when a significant differential linear response between dryland and irrigated treatments was detected (Fig. 1). (A differential linear response implies that root length distribution throughout the soil profile follows different linear functions for the treatments compared.) Root length proliferation was greater in the $0.45-$ to $1.20-\mathrm{m}$ depth for dryland than irrigated corn V14. By R2, there were significant differential linear responses of irrigated and dryland treatments as well as between 50 and $100 \%$ irrigation treatments. These responses were characterized by greater root length in the upper $0.60 \mathrm{~m}$ of soil for the $100 \%$ irrigation treatment than for water-deficit treatments (dryland and 50\% irrigation.) This response was associated with a trend toward greater total root length for the $100 \%$ irrigated treatment (Table 1). The $50 \%$ irrigation and dryland treatments exhibited less root length at the soil surface $(0-0.15 \mathrm{~m})$, while overall root length proliferation occurred progressively deeper within the soil profile.

\section{Tillage Effects}

Although chiseling was not performed until V6, there was a trend toward greater root length in the 0 - to 0.60-m depth for chisel treatments at V8 compared to either disc or no-tillage treatments (Fig. 2). Both chisel and no-tillage treatments retained corn stalk residue on the soil surface. Surface residue, with its waterconserving effect, encouraged proliferation of roots in the top $0.15 \mathrm{~m}$ of soil. Disc treatments were associated with less root length at this soil depth, presumably due to drier surface soil. The trend toward fewer surface

Table 1. Comparisons of total profile root lengths for irrigation and tillage treatment means at three growth stages. $\dagger$

\begin{tabular}{|c|c|c|c|c|}
\hline \multirow[b]{3}{*}{ Comparison } & \multicolumn{4}{|c|}{$\begin{array}{l}\text { Total root length per } \\
\text { surface land area }\end{array}$} \\
\hline & \multicolumn{4}{|c|}{ Growth stage } \\
\hline & V8 & & V14 & $\mathrm{R} 2$ \\
\hline & & & $\mathrm{km} / \mathrm{m}^{2}$ & \\
\hline $\begin{array}{l}\text { Chisel vs. } \\
\text { Disc }\end{array}$ & $\begin{array}{l}3.27 \\
2.75\end{array}$ & $* * *$ & $\begin{array}{l}4.71 \\
3.83\end{array} \mathrm{NS}$ & $\begin{array}{l}5.69 \\
4.46\end{array}$ NS \\
\hline $\begin{array}{l}\text { No-till vs. } \\
\text { Mean of chisel and disc }\end{array}$ & $\begin{array}{l}2.63 \\
3.01\end{array}$ & NS & $\begin{array}{l}4.72 \\
4.27\end{array}$ & $\begin{array}{l}4.76 \\
5.07\end{array}$ \\
\hline $\begin{array}{l}100 \% \text { irrigation vs. } \\
50 \% \text { irrigation }\end{array}$ & $\begin{array}{l}2.81 \\
2.69\end{array}$ & NS & $\begin{array}{l}4.82 \\
3.78\end{array}$ & $\begin{array}{l}5.50 \\
4.60\end{array} \mathrm{NS}$ \\
\hline $\begin{array}{l}\text { Dryland vs. } \\
\text { Mean of } 50 \% \text { and } 100 \% \text { irrigation }\end{array}$ & $\begin{array}{l}3.43 \\
2.75\end{array}$ & $* * *$ & $\begin{array}{l}4.92 \\
4.30\end{array}$ & $\begin{array}{l}4.65 \\
5.05\end{array}$ \\
\hline
\end{tabular}

*** Means are significantly different at $10 \%$ level by single degree-offreedom comparisons. NS = not significant.

$\dagger$ Root length totals are a summation of eight 0.15 -m-depth increments for stages V8 and V14 and ten 0.15-m-depth increments for R2.

\footnotetext{
$\overline{{ }^{3} \text { Mention }}$ of a trademark or proprietary product does not constitute a guarantee or warranty by the USDA and does not imply approval to the exclusion of other similar products.
} 


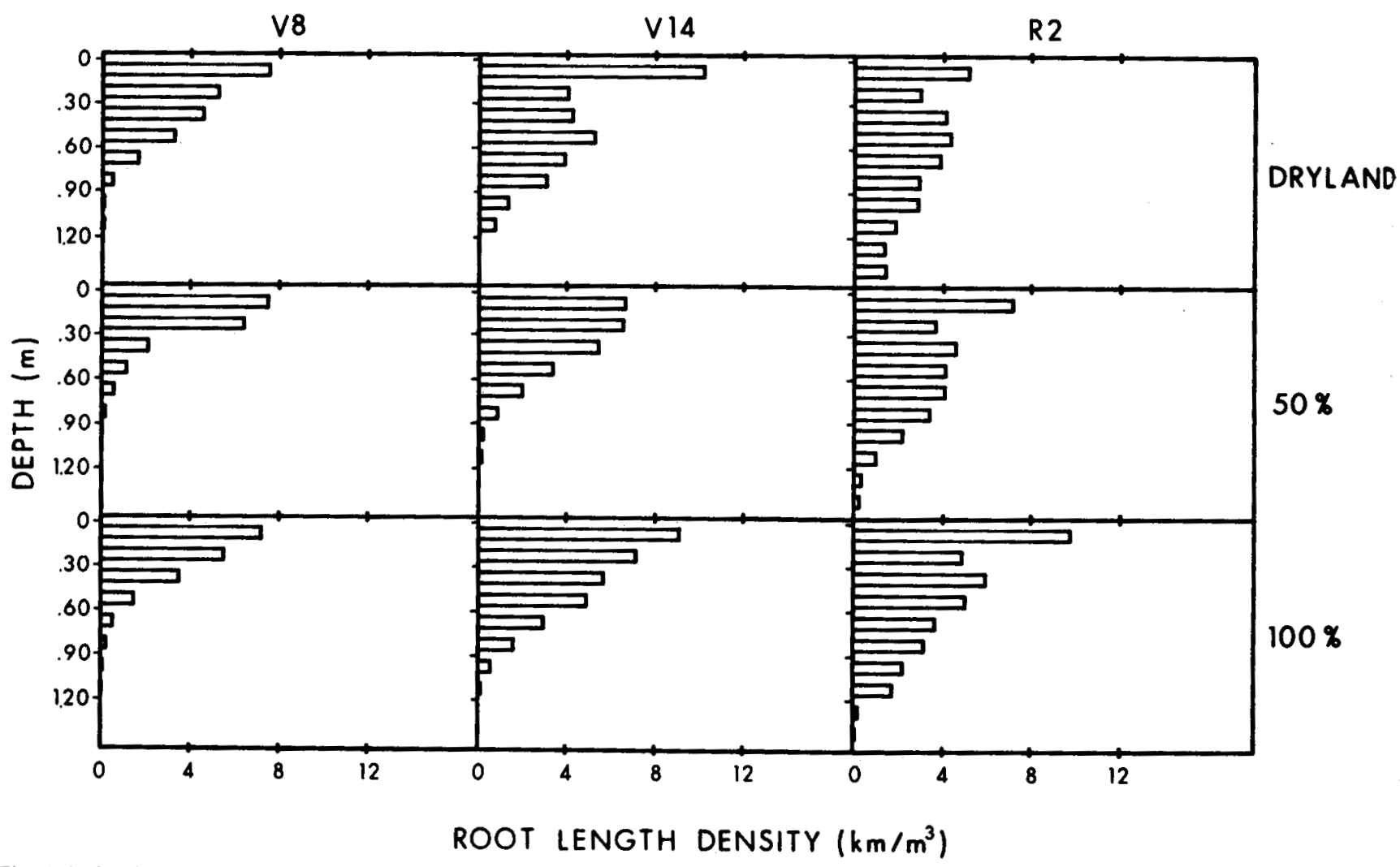

Fig. 1. Irrigation treatment effect on corn root length at three growth stages. Orthogonal polynomials showed significant $(P<0.01)$ linear root distribution with depth at all three corn growth stages and significant $(P<0.01)$ differential response of root length distribution for dryland vs. irrigated treatments at V14 and $R 2$.

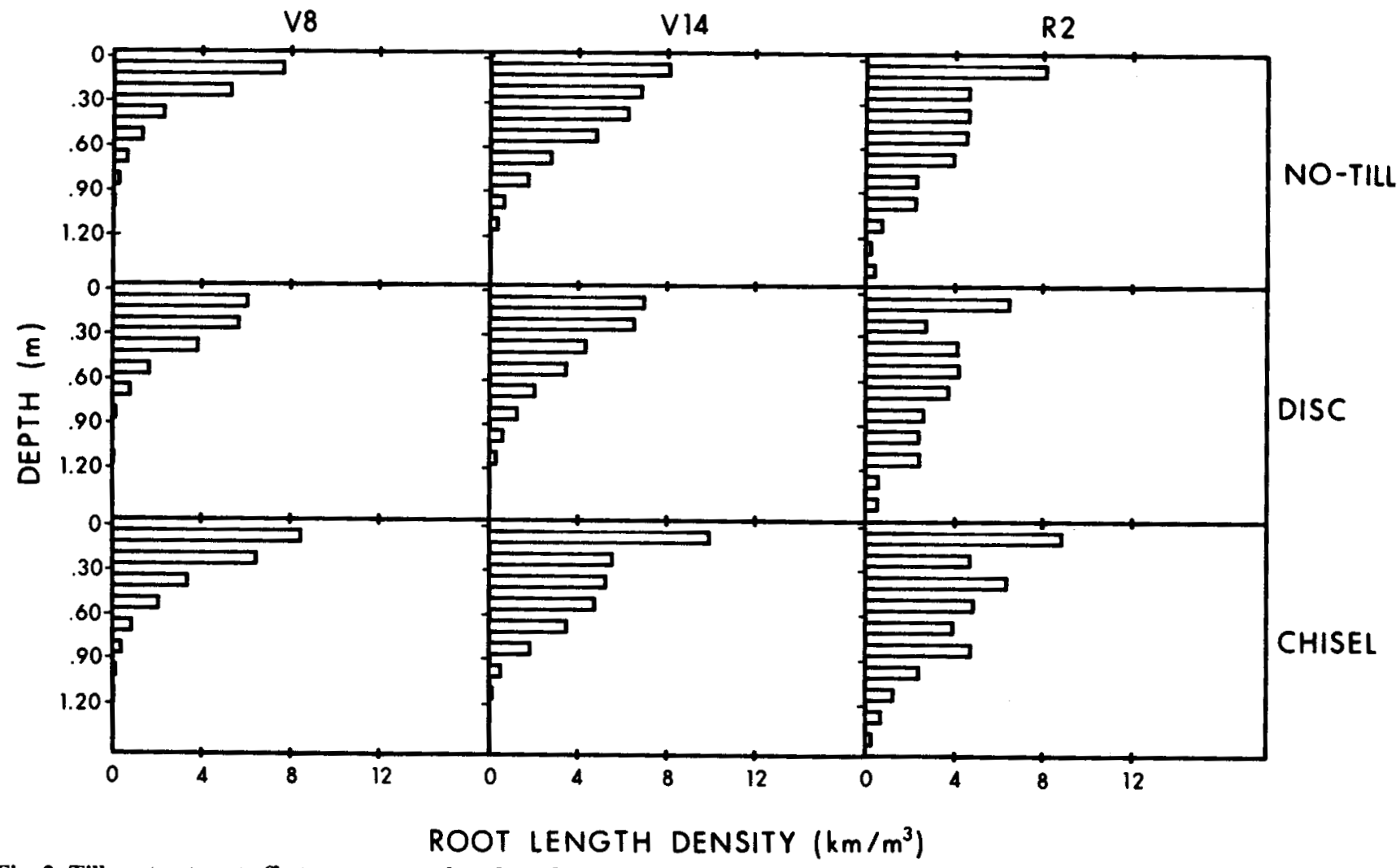

Fig. 2. Tillage treatment effect on corn root length at three growth stages. Orthogonol polynomials showed significant $(P<0.01)$ linear root length distribution with depth at all three corn growth stages and significant $(P<0.05)$ differential linear response of root length to chisel vs. disc treatments at $\mathbf{R 2}$. 


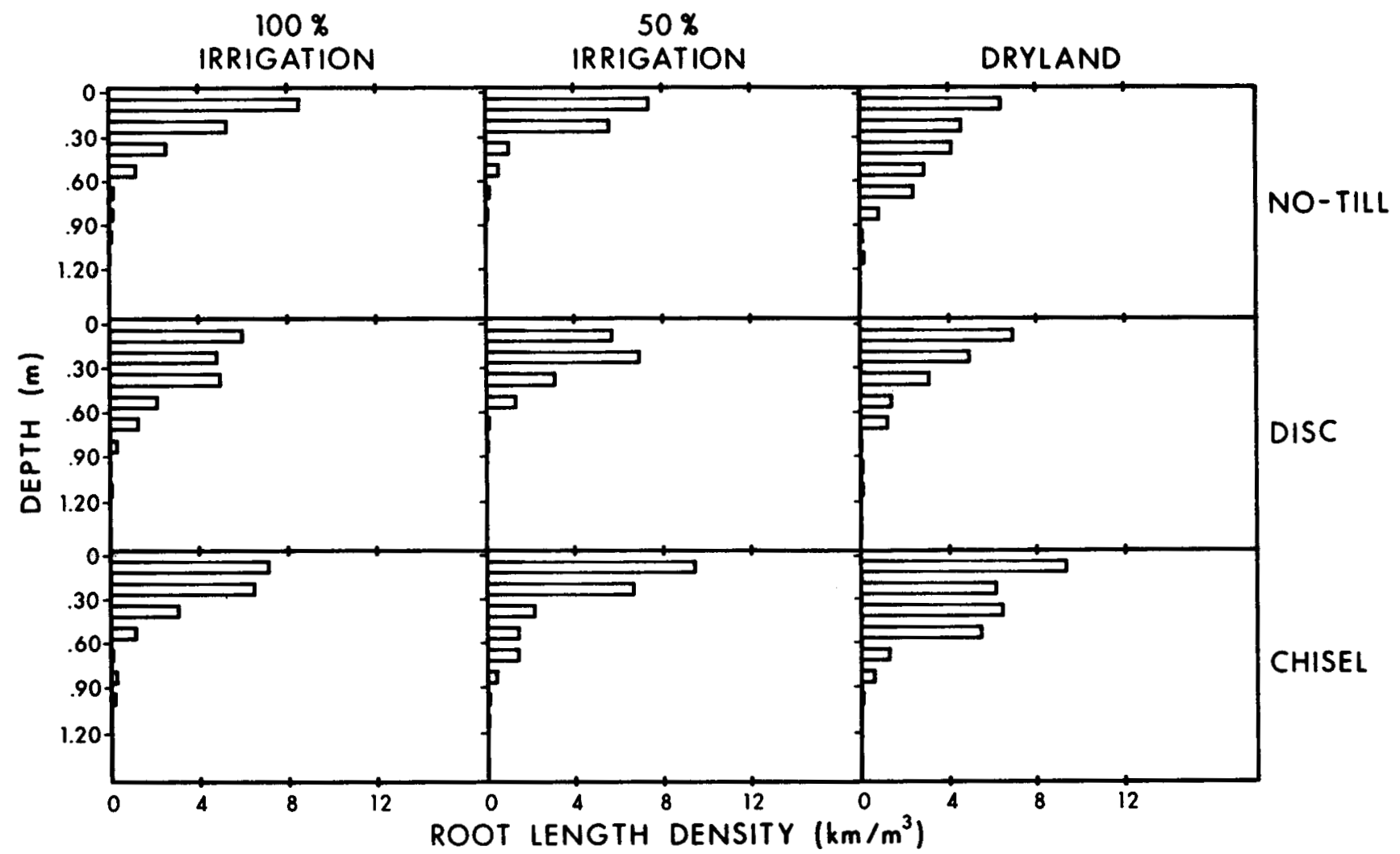

Fig. 3. Irrigation-by-tillage treatment effect on corn root length at V8. Orthogonal polynomials showed significant linear $(P<0.01)$ and quadratic root length distribution with depth for all treatment combinations.

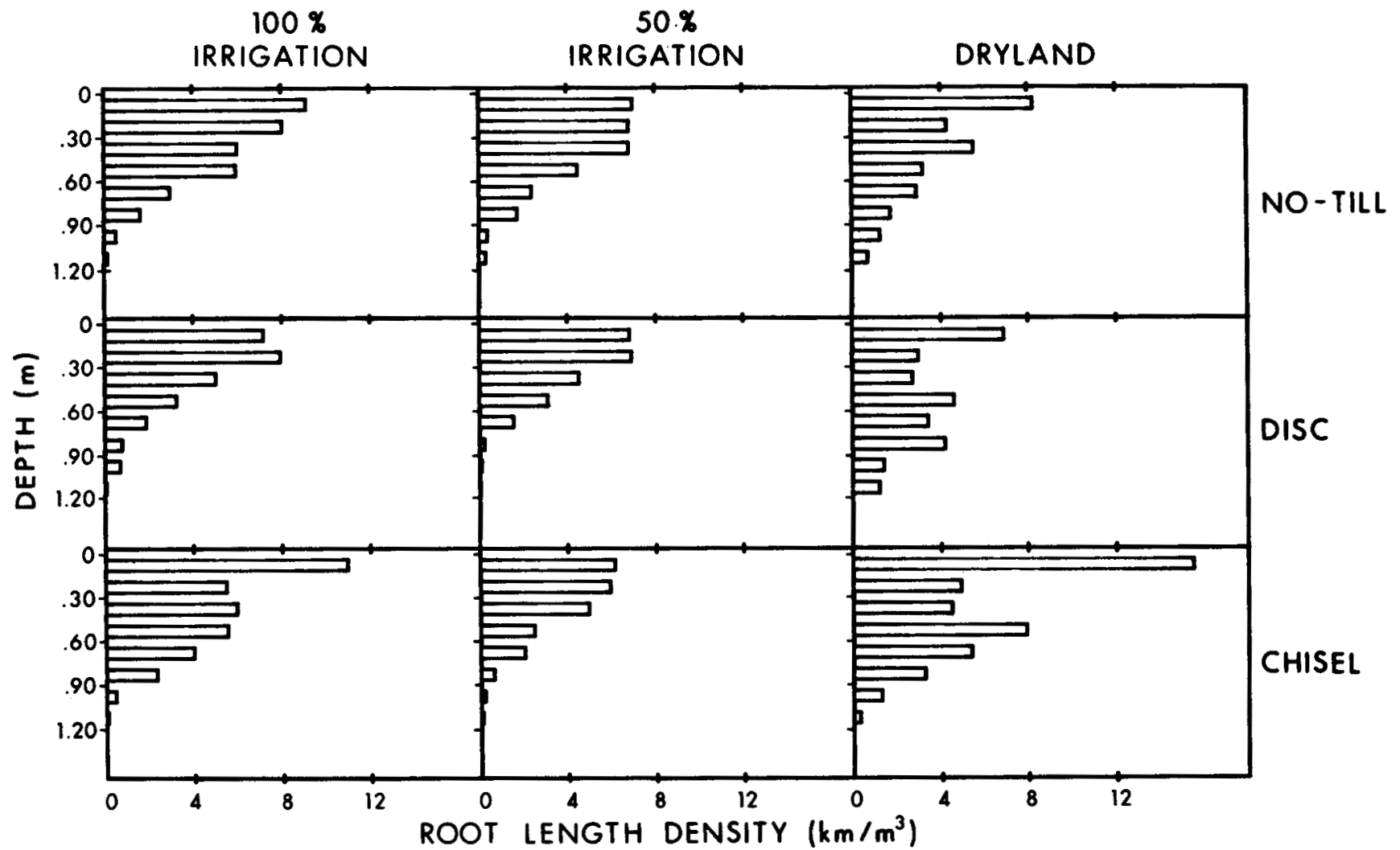

Fig. 4. Irrigation-by-tillage treatment effect on corn root length at V14. Orthogonal polynomials showed significant linear $(P<0.01)$ root length distribution with depth for all treatment combinations and significant $(P<0.01)$ differential linear response of root length distribution for chisel vs. disc treatments in combination with dryland. 


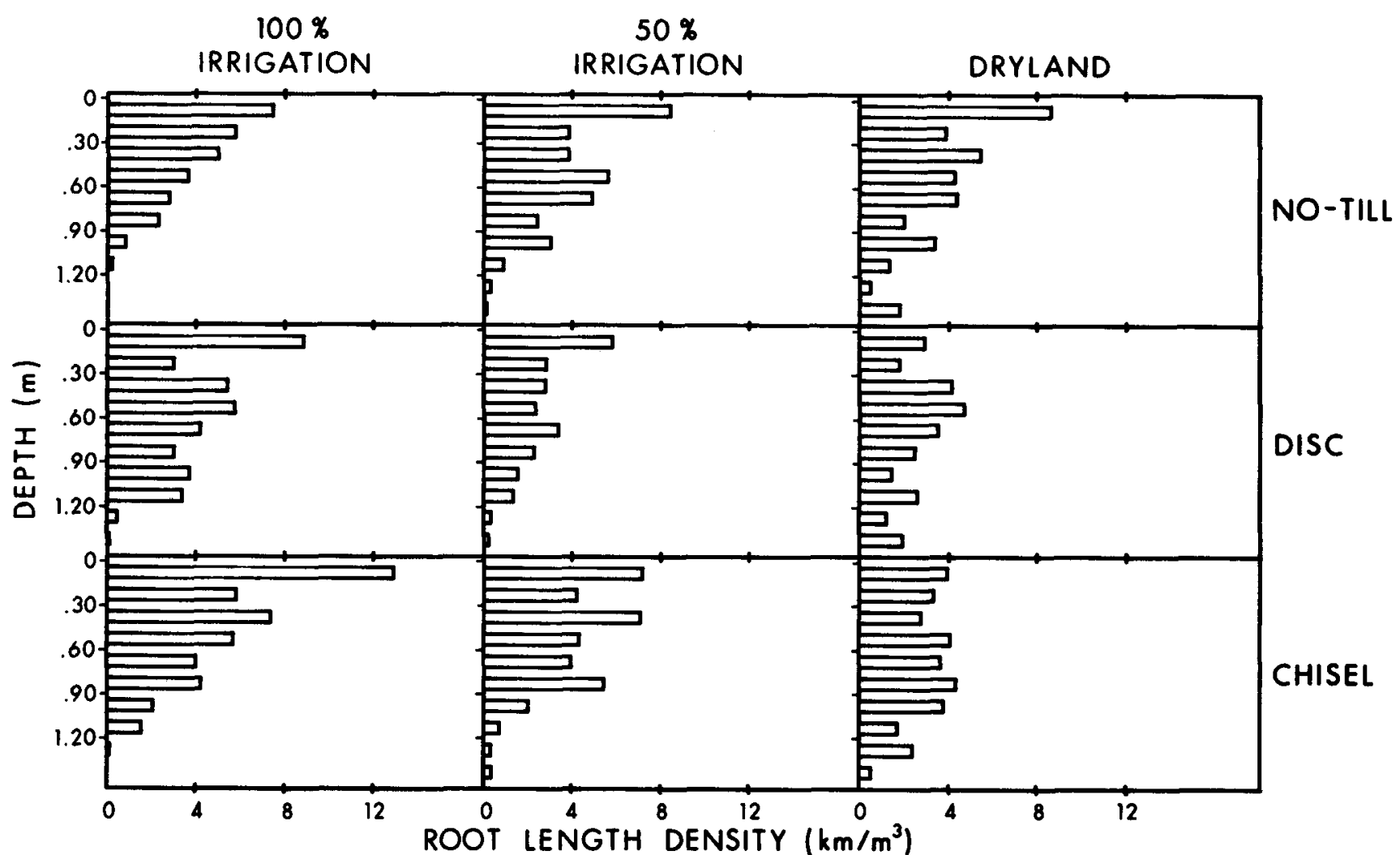

Fig. 5. Irrigation-by-tillage treatment effect on corn root length at $R 2$. Orthogonal polynomials showed significant linear $(P<0.01)$ root length distribution with depth for all treatment combinations and significant $(P<0.01)$ differential linear response of root length distribution for chisel vs. disc treatments in combination with $100 \%$ irrigation.

roots under disc treatments occurred at each of the three sampling dates (Fig. 2).

At R2, there was a significant differential linear response of chisel and disc treatments. This differential response was characterized by less root length for disc treatments in the top $0.90 \mathrm{~m}$ soil. Surface residue maintenance of chisel and no-tillage treatments affected root growth habits well below the soil surface. Although there was a trend toward less total profile root length with disc treatments at all three sampling dates, the differences were not significant (Table 1).

\section{Irrigation $\times$ Tillage Interaction}

No significant irrigation $\times$ tillage interaction was observed; however, it is interesting to note some of the relative differences in root length that occurred under various treatment combinations. Differences in root length distribution at V8 did not appear constant for chisel and no-tillage across all irrigation treatments (Fig. 3). Root length in the $0-$ to $0.75-\mathrm{m}$ soil depth increased as irrigation decreased. Such an effect would have to be due to carryover effects related to irrigation treatments in previous years since no irrigation was applied prior to the V8 sampling date during 1980 . After one irrigation, root length proliferation at V14 exhibited some changes in response to irrigation-tillage treatment combinations (Fig. 4). At this growth stage, chisel and disc treatments showed a greater proportion of root length deeper in the profile for dryland treatments than irrigated treatments. It would appear that water deficit under dryland conditions results in roots proliferating deeper into the soil profile.

No-tillage and disc treatments had relatively similar responses across irrigation treatments at V14, but chisel treatments did not. The water deficit under dryland treatments at V14 resulted in greater total root length throughout most of the soil profile in combination with chisel treatments. This led to a significant differential linear response of chisel vs. disc treatments under dryland conditions. Discing seemed to promote a relatively greater proportion of corn root length deeper in the soil profile.

Corn grown with no tillage encouraged root growth near the soil surface regardless of irrigation treatment. Surface root length and total profile root length of corn in disc and chisel treatments decreased with $50 \%$ irrigation and dryland treatments at the $\mathrm{R} 2$ sampling date (Fig. 5). Chiseling caused a significant differential linear response of root length distribution when compared to disc treatments under full irrigation at R2; however, relative differences in root length distribution were not apparent when compared in combination with $50 \%$ irrigation and dryland treatments.

\section{DISCUSSION}

Factors influencing corn root length distributior within the scope of this study included irrigation, tillage, and their interaction effects upon the crop/soil environment. Irrigation amount affected root distribution within the soil profile and total root length such 
that relatively deeper root proliferation was observed with dryland treatments. Other researchers (Robertson et al., 1980; Mayaki et al., 1976) observed that soil water deficit forced deeper root proliferation. This trend was observed even at the V8 growth stage, prior to irrigation. No differences in root length distribution (due to irrigation amount) would be expected until after the first irrigation because the soil was at field capacity at the beginning of the study. Yearly root proliferation deep within the soil profile under a water deficit may have promoted greater tilth, water-holding capacity, improved soil structure, and a more favorable rooting environment as a result of annual deposition of root residues. Subsequent root proliferation deep within the soil profile at an early growth stage could enable corn to draw on more stored soil water during periods of water deficit. However, growing seasons such as that of 1980 , with extreme heat and drought stress, impose evapotranspirational demands well beyond the capability of most soils to supply water even with deep root penetration. Deeper profile root proliferation would hold greatest potential for reducing irrigation only in years of moderate water stress. The effects of water stress on deep profile rooting were even more pronounced as the season progressed. Water deficit at the V14 and R2 growth stages encouraged deeper overall root length proliferation. Soil-water relations are discussed here only in a general sense because soil moisture data were not replicated and are not reported here.

The chisel and no-tillage treatments left crop residue at the soil surface. The water-conserving effect of this residue encouraged surface root proliferation. Discing tended to inhibit surface root length proliferation as well as deep profile rooting to some extent. Possible causes for this observation include drier soil without the water-conserving benefits of the surface residue and possible compaction due to the discing operation.

The deep chisel treatment used in this study was originally intended to increase irrigation water infiltration rates by providing an open "slot" into the soil. However, chiseling during the growing season as a means of increasing water infiltration rates on sloped soils should be done soon after crop emergence, before root growth is far advanced, to avoid root pruning. As performed in this study, the chisel treatment resulted in plants displaying visible signs of water stress for a few days at V6; however, at R2, chiseling had slightly greater root length than did other tillage treatments except under dryland conditions.

No-tillage treatments (with undisturbed surface residue) were associated with prolific root development and root length near the soil surface, especially when water stress became more severe in dryland and 50\% irrigation treatments during R2. It appears that no- tillage holds the greatest potential of the three tillage treatments used for prolonging the onset of water stress to corn during drought (Bond and Willis, 1969). This can be critical for maintaining nutrient uptake and adequate plant nutrient status, ultimately having advantageous effects on grain yield [Wilhelm et al. (1985) reported the effects of irrigation and tillage on grain yield and components of yield]. Increasing costs and demands for limited water resources in many areas may force producers to consider using less water for irrigated corn production. It may be possible to use no-tillage and conserve soil moisture to reduce overall water applications while maintaining yields.

\section{REFERENCES}

Bausch, W., A.B. Anker, C.W. Wendt, and O.C. Wilke. 1977. A selfpropelled high-clearance soil coring machine. Agron. J. 69:122124.

Bond, J.J., and W.O. Willis. 1969. Soil water evaporation: Surface residue rate and placement effects. Soil Sci. Soc. Am. Proc. 33:445448.

Chaudhary, M.R., and S.S. Prihar. 1974. Root development and growth response of corn following mulching, cultivation, or interrow compaction. Agron. J. 66:350-355.

Gilley, J.R., and L.N. Mielke. 1980. Conserving energy with lowpressure center pivots. J. Irrig. Drain. Div. Am. Soc. Civ. Eng. 106:49-59.

$\longrightarrow$, and W.W. Wilhelm. 1983. An experimental centerpivot irrigation system for reduced energy production studies. Trans. ASAE 26:1375-1379, 1385.

Griffith, D.R., J.V. Mannering, H.M. Galloway, S.D. Parsons, and C.B. Richey. 1973. Effect of eight tillage-planting systems on soil temperature, percent stand, plant growth, and yield of corn on five Indiana soils. Agron. J. 65:321-326.

Hill, J.D., and R.L. Blevins, 1973. Quantitative soil moisture use in corn grown under conventional and no-tillage methods. Agron. J. 65:945-949.

Mayaki, W.C., L.R. Stone, and I.D. Teare. 1976. Irrigated and nonirrigated soybean, corn, and grain sorghum root systems. Agron. J. 68:532-534.

Mielke, L.N., and W.W. Wilhelm. 1983. Mast anchor for hydraulic soil-sampling machines. Soil Sci. Soc. Am. J. 47:1263-1264.

Nelson, L.A., and J.O. Rawlings. 1983. Ten common misuses of statistics in agronomic research and reporting. J. Agron. Educ. 12:100-105.

Newman, E.I. 1966. A method of estimating the total length of root in a sample. J. Appl. Ecol. 3:139-145.

Robertson, W.K., L.C. Hammond, J.T. Johnson, and K.J. Boote. 1980. Effects of plant-water stress on root distribution of corn, soybeans, and peanuts in sandy soil. Agron. J. 72:548-550.

Steel, R., and J. Torrie. 1980. Principles and procedures of statistics. 2nd ed. McGraw-Hill Book Co., New York.

Tscheschke, P., J.R. Gilley, T. Thompson, and P. Fischbach. 1978. IRRIGATE-A scheduling model. Agric. Eng. 59:45-46.

Van Doren, D.M., and G.B. Triplett. 1969. Mechanism of corn (Zea mays L.) response to cropping practices without tillage. Ohio Agric. Res. Dev. Cent. Res. Circ. 169.

Ward, K.J., B. Klepper, R.W. Rickman, and R.R. Allmaras. 1978. Quantitative estimation of living wheat-root lengths in soil cores Agron. J. 70:675-677.

Wilhelm, W.W., L.N. Mielke, and J.R. Gilley. 1985. Tillage and low-pressure center-pivot irrigation effects on corn yield. Agron. J. 77-258-263.

J.M. Norman, and R.L. Newell. 1983. Seimautomated XY-plotter-based method for measuring root lengths. Agron. J. 75:149-152. 